\title{
Lupane Glycosides from the Leaves of Acanthopanax koreanum
}

\author{
Hyun-Sik ChoI, ${ }^{a}$ Hyoung Ja Kim,${ }^{b}$ Sang-Gil NAm, ${ }^{a}$ In-Seon Kim, ${ }^{a}$ Kyung-Tae LeE, ${ }^{a}$ \\ Chang-Soo Yook, ${ }^{a}$ and Yong Sup LeE*,a \\ ${ }^{a}$ Kyung Hee East-West Pharmaceutical Research Institute, College of Pharmacy and Department of Life and \\ Nanopharmaceutical Science, Kyung Hee University; 1 Hoegi-dong, Dongdaemun-ku, Seoul 130-701, Korea: and ${ }^{b}$ Life \\ Sciences Division, Korea Institute of Science and Technology; P. O. Box 131, Cheongryang, Seoul 130-650, Korea. \\ Received July 11, 2008; accepted August 26, 2008
}

Three new lupane-type saponins, acankoreosides $\mathrm{F}-\mathrm{H}(1-3)$ were isolated from the methanol extract of the leaves of Acanthopanax koreanum NAKAI. The structures of these three saponins were established by chemical and spectroscopic analysis as 3 $\alpha, 30$-dihydroxylup-20(29)-en-23,28-dioic acid 28- $O$-[ $\alpha$-L-rhamnopyranosyl-(1 $\rightarrow 4)$ -

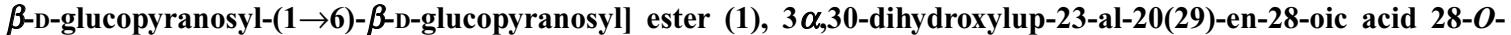

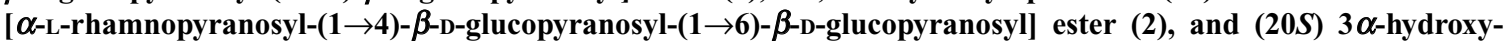
lup-23-al-28,29-dioic acid 28- $O$-[ $\alpha$-L-rhamnopyranosyl-( $\rightarrow 4)$ - $\beta$-D-glucopyranosyl-( $1 \rightarrow 6)$ - $\beta$-D-glucopyranosyl] ester (3), respectively. The effects of the isolates $(1-3)$ on the lipopolysaccharide-induced production of nitric oxide and prostaglandin $E_{2}$ were evaluated in RAW 264.7 macrophages.

Key words Acanthopanax koreanum; Araliaceae; lupane glycoside; acankoreoside

Acanthopanax koreanum is a shrub that belongs to the Araliaceae family and is found in Northeast Asia. Acanthopanax species, such as, $A$. senticosus, A. gracilistylus, $A$. obovatus, and $A$. giraldii have been used to treat rheumatism, allergies, and diabetes, ${ }^{1-4)}$ and the root and stem bark of $A$. koreanum are used as a tonic, as a prophylactic, and to treat rheumatism, paralysis, hepatitis, and diabetes by practitioners of oriental medicine. ${ }^{5,6)}$ The biological activities of lignans and diterpenes from the roots and stems of $A$. koreanum have been well established. ${ }^{7-11)}$ In addition, our group has previously reported on lupane-triterpene glycosides, such as, acankoreosides $\mathrm{A}-\mathrm{E}$, obtained from the leaves of $A$. koreanum. ${ }^{12-14)}$

During our on-going investigation of the bioactive principles of $A$. koreanum, we isolated and determined the structures of three lupane-type saponins, $3 \alpha, 30$-dihydroxylup20(29)-en-23,28-dioic acid 28- $O$-[ $\alpha$-L-rhamnopyranosyl$(1 \rightarrow 4)$ - $\beta$-D-glucopyranosyl- $(1 \rightarrow 6)$ - $\beta$-D-glucopyranosyl] ester (1), $3 \alpha, 30$-dihydroxylup-23-al-20(29)-en-28-oic acid 28-O[ $\alpha$-L-rhamnopyranosyl-( $1 \rightarrow 4)$ - $\beta$-D-glucopyranosyl-( $1 \rightarrow 6)-\beta$ D-glucopyranosyl] ester (2), and (20S) $3 \alpha$-hydroxylup-23al-28,29-dioic acid 28- $O$-[ $\alpha$-L-rhamnopyranosyl-( $1 \rightarrow 4)-\beta$-Dglucopyranosyl-( $1 \rightarrow 6)$ - $\beta$-D-glucopyranosyl] ester $(3)$, which we refer to as acankoreosides $\mathrm{F}-\mathrm{H}$, respectively. In addition, we evaluated their anti-inflammatory activities in RAW 264.7 macrophages.

\section{Results and Discussion}

Compound 1 was obtained as a white amorphous powder of molecular formula $\mathrm{C}_{48} \mathrm{H}_{75} \mathrm{O}_{20}$, as determined by HR-FABMS (molecular ion at $\mathrm{m} / z 971.4863$ attributed to $[\mathrm{M}-\mathrm{H}]^{-}$). The structure of 1 was established by comparing its chemical shifts to those of acankoreoside A $\mathbf{4}$ in ${ }^{1} \mathrm{H}-\mathrm{NMR}$ spectra, ${ }^{12)} \mathbf{1}$ differed from acankoreoside A due to a hydroxylated methylene group at $\delta 4.42$ and 4.47 (each d, $J=15.3 \mathrm{~Hz}$ ) rather than the secondary methyl group at $\mathrm{C}-30$ in acankoreoside $\mathrm{A}$. The position of this methylene group (C-30) was elucidated due to correlations in the HMBC spectrum between $\mathrm{C}-20$ at $\delta$ 156.5 and H-18 $(\delta$ 1.91), H-19 ( $\delta 3.33), \mathrm{H}-29(\delta$ 5.08) and H-30 ( $\delta 4.42,4.47)$ of 1 . The ${ }^{1} \mathrm{H}-\mathrm{NMR}$ spectrum of 1 showed signals due to four tertiary methyl groups at $\delta 0.89$, $0.92,1.17$ and 1.44 (each $3 \mathrm{H}, \mathrm{s}$ ), one secondary methyl group at $\delta 1.69(3 \mathrm{H}, \mathrm{d}, J=6.0 \mathrm{~Hz})$, which was assigned to $\mathrm{H}-$ 6 of rhamnose, three anomeric protons due to two hexosyl residues at $\delta 6.30(1 \mathrm{H}, \mathrm{d}, J=8.0 \mathrm{~Hz})$ and $4.96(1 \mathrm{H}, \mathrm{d}$, $J=7.9 \mathrm{~Hz})$, and one 6-deoxyhexosyl residue at $\delta 5.82(1 \mathrm{H}$, brs); as detailed in Tables 1 and 2 . Furthermore, the ${ }^{1} \mathrm{H}$ NMR spectrum of 1 showed characteristic signals for $\mathrm{H}-19$ at $\delta 3.33(1 \mathrm{H}, \mathrm{dt}, J=3.6,11.5 \mathrm{~Hz}), \mathrm{H}-13$ at $\delta 2.61(1 \mathrm{H}, \mathrm{m}), \mathrm{H}-5$ at $\delta 2.48(1 \mathrm{H}$, br d, $J=11.0 \mathrm{~Hz})$, and $\mathrm{H}-3$ at $\delta 4.21(1 \mathrm{H}$, overlapped), which suggested an aglycone with a $3 \alpha$-hydroxylupan-28-oic acid skeleton. The ${ }^{13} \mathrm{C}-\mathrm{NMR}$ spectrum of $\mathbf{1}$ showed signals at $\delta 175.1$ and 181.2 , indicating the presence of an ester carboxyl group at C-28 and a free carboxylic acid at $\mathrm{C}-23$ on the triterpene moiety. The assignment of the $\alpha$ hydroxyl group at C-3 was performed by comparing spectral data to literature values. ${ }^{14-16)}$ Observed chemical shifts of $\mathrm{C}$ $1(\delta 33.2), \mathrm{C}-5(\delta 45.4)$ and C-24 ( $\delta$ 18.2) in the aglycone of 1 confirmed the axial $\alpha$-position of the 3-hydroxyl group by comparing the corresponding signals of the $3 \beta$-epimer derivative $[\delta$ value for $39.4(\mathrm{C}-1), 52.4(\mathrm{C}-5)$ and $\left.11.3(\mathrm{C}-24)] .{ }^{16}\right)$
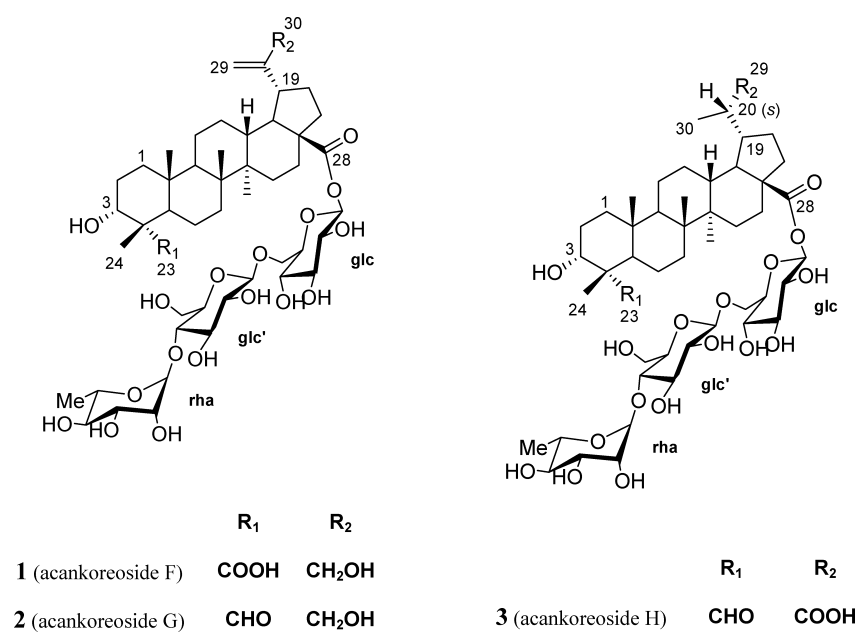

Fig. 1. Compounds $\mathbf{1}-\mathbf{3}$ Isolated from Acanthopanax koreanum 
Table 1. NMR Data of Acankoreosides F-H (1-3) $\left(125,500 \mathrm{MHz}\right.$, Pyridine- $\left.d_{5}\right)$

\begin{tabular}{|c|c|c|c|c|c|c|}
\hline \multirow{2}{*}{ No. } & \multicolumn{2}{|l|}{1} & \multicolumn{2}{|l|}{2} & \multicolumn{2}{|l|}{3} \\
\hline & $\delta_{\mathrm{H}}$ (mult., $\mathrm{Hz}$ ) & $\delta_{\mathrm{C}}$ & $\delta_{\mathrm{H}}($ mult., $\mathrm{Hz})$ & $\delta_{\mathrm{C}}$ & $\delta_{\mathrm{H}}($ mult., $\mathrm{Hz})$ & $\delta_{\mathrm{C}}$ \\
\hline 1 & $1.44,1.81(\mathrm{~m})$ & 33.2 & $1.45,1.94(\mathrm{~m})$ & 33.1 & $1.49,1.80(\mathrm{~m})$ & 33.1 \\
\hline 2 & $1.93,1.98(\mathrm{~m})$ & 26.1 & $1.75,1.94(\mathrm{~m})$ & 26.7 & $1.76,1.93(\mathrm{~m})$ & 26.7 \\
\hline 3 & 4.21 (overlapped) & 72.8 & $4.01(\mathrm{brs})$ & 73.0 & $4.02(\mathrm{brs})$ & 73.0 \\
\hline 4 & & 51.8 & & 52.5 & & 52.5 \\
\hline 5 & $2.48(\mathrm{brd}, 11.0)$ & 45.4 & $2.40(\mathrm{brd}, 12.1)$ & 44.0 & $2.42(\mathrm{brd}, 13.3)$ & 44.0 \\
\hline 6 & $1.58,1.81(\mathrm{~m})$ & 21.7 & $1.16,1.45(\mathrm{~m})$ & 20.9 & $1.10,2.15(\mathrm{~m})$ & 21.1 \\
\hline 7 & $1.31,1.69(\mathrm{~m})$ & 34.5 & $1.23,1.57(\mathrm{~m})$ & 34.1 & $1.25,1.59(\mathrm{~m})$ & 34.1 \\
\hline 8 & & 41.8 & & 41.8 & & 41.8 \\
\hline 9 & $1.61(\mathrm{~m})$ & 51.0 & $1.57(\mathrm{~m})$ & 50.6 & $1.66(\mathrm{~m})$ & 50.2 \\
\hline 10 & & 37.4 & & 36.9 & & 36.9 \\
\hline 11 & $1.31,1.45(\mathrm{~m})$ & 21.0 & $1.07,1.33(\mathrm{~m})$ & 21.0 & $1.19,1.48(\mathrm{~m})$ & 20.8 \\
\hline 12 & $1.17,1.68(\mathrm{~m})$ & 27.1 & $1.16,1.33(\mathrm{~m})$ & 27.0 & $1.21,1.86(\mathrm{~m})$ & 26.9 \\
\hline 13 & $2.61(\mathrm{~m})$ & 38.3 & $2.64(\mathrm{~m})$ & 38.3 & $2.70(\mathrm{~m})$ & 38.2 \\
\hline 14 & & 42.8 & & 42.8 & & 43.0 \\
\hline 15 & $1.17,2.01(\mathrm{~m})$ & 30.2 & $1.16,1.98(\mathrm{~m})$ & 30.1 & $1.18,2.01(\mathrm{~m})$ & 30.0 \\
\hline 16 & $1.44,2.61(\mathrm{~m})$ & 32.2 & $1.45,2.64(\mathrm{~m})$ & 32.1 & $1.46,2.65(\mathrm{~m})$ & 32.1 \\
\hline 17 & & 57.0 & & 56.9 & & 57.3 \\
\hline 18 & $1.91(\mathrm{~m})$ & 50.2 & $1.95(\mathrm{~m})$ & 50.2 & $1.55(\mathrm{t}, 11.0)$ & 48.9 \\
\hline 19 & $3.33(\mathrm{dt}, 3.6,11.5)$ & 43.2 & $3.34(\mathrm{dt}, 4.0,11.5)$ & 43.2 & $3.53(\mathrm{~m})$ & 40.6 \\
\hline 20 & & 156.5 & & 156.5 & $2.98(\mathrm{dq}, 2.7,6.9)$ & 42.1 \\
\hline 21 & $1.58,2.30(\mathrm{~m})$ & 32.7 & $1.57,2.30(\mathrm{~m})$ & 32.7 & $1.88,2.11(\mathrm{~m})$ & 25.0 \\
\hline 22 & $1.58,2.19(\mathrm{~m})$ & 36.8 & $1.57,2.18(\mathrm{~m})$ & 36.7 & $1.41,2.19(\mathrm{~m})$ & 37.3 \\
\hline 23 & & 181.2 & $9.93(\mathrm{~s})$ & 209.8 & $10.0(\mathrm{~s})$ & 209.9 \\
\hline 24 & $1.44(\mathrm{~s})$ & 18.2 & $1.09(\mathrm{~s})$ & 14.6 & $1.10(\mathrm{~s})$ & 14.6 \\
\hline 25 & $0.92(\mathrm{~s})$ & 16.8 & $0.85(\mathrm{~s})$ & 16.4 & $0.87(\mathrm{~s})$ & 16.3 \\
\hline 26 & $1.17(\mathrm{~s})$ & 16.7 & $1.14(\mathrm{~s})$ & 16.5 & $1.16(\mathrm{~s})$ & 16.5 \\
\hline 27 & $0.89(\mathrm{~s})$ & 14.9 & $0.94(\mathrm{~s})$ & 14.8 & $0.94(\mathrm{~s})$ & 14.9 \\
\hline 28 & & 175.1 & & 175.0 & & 174.9 \\
\hline 29 & $5.08,5.49(\mathrm{br} \mathrm{s})$ & 106.1 & $5.10,5.50(\mathrm{brs})$ & 106.1 & & 180.0 \\
\hline 30 & $4.42,4.47$ (each d, 15.3) & 64.3 & $4.42,4.47$ (each d, 15.3$)$ & 64.3 & $1.28(\mathrm{~d}, 6.9)$ & 10.0 \\
\hline
\end{tabular}

Table 2. The Sugar Moieties of Acankoreosides F-H $(\mathbf{1}-\mathbf{3})\left(125,500 \mathrm{MHz}\right.$, Pyridine- $\left.d_{5}\right)$

\begin{tabular}{|c|c|c|c|c|c|c|}
\hline \multirow{2}{*}{ No. } & \multicolumn{2}{|l|}{1} & \multicolumn{2}{|l|}{2} & \multicolumn{2}{|l|}{3} \\
\hline & $\delta_{\mathrm{H}}($ mult., $\mathrm{Hz}$ ) & $\delta_{\mathrm{C}}$ & $\delta_{\mathrm{H}}$ (mult., Hz) & $\delta_{\mathrm{C}}$ & $\delta_{\mathrm{H}}($ mult., $\mathrm{Hz})$ & $\delta_{\mathrm{C}}$ \\
\hline \multicolumn{7}{|l|}{ 28-glc } \\
\hline 1 & $6.30(\mathrm{~d}, 8.0)$ & 95.2 & $6.32(\mathrm{~d}, 8.2)$ & 95.2 & $6.33(\mathrm{~d}, 8.0)$ & 95.2 \\
\hline 2 & $4.10(\mathrm{dd}, 8.2,8.5)$ & 74.0 & $4.10($ brt, 8.9$)$ & 74.0 & $4.08(\mathrm{brt}, 8.6)^{a)}$ & 74.0 \\
\hline 3 & $4.23(\mathrm{dd}, 8.1,9.0)$ & 78.6 & $4.22(t, 9.0)$ & 78.6 & $4.23(t, 9.0)$ & 78.6 \\
\hline 4 & $4.29(\mathrm{t}, 9.2)$ & 70.8 & $4.31(\mathrm{t}, 9.3)$ & 70.7 & $4.38(t, 9.5)$ & 70.5 \\
\hline 5 & $4.08^{a)}$ & 78.1 & $4.08^{a)}$ & 78.1 & $4.07^{a)}$ & 77.8 \\
\hline 6 & $4.28(\mathrm{dd}, 5.3,12.7)$ & 69.3 & $4.29^{a)}$ & 69.3 & $4.28(\mathrm{dd}, 4.3,11.2)$ & 69.3 \\
\hline & $4.67^{a)}$ & & $4.67^{a)}$ & & $4.61(\mathrm{dd}, 2.0,11.4)$ & \\
\hline \multicolumn{7}{|l|}{ 6-glc } \\
\hline $1^{\prime}$ & $4.96(\mathrm{~d}, 7.9)$ & 104.9 & $4.95(\mathrm{~d}, 7.6)$ & 104.9 & $4.90(\mathrm{~d}, 7.8)$ & 105.1 \\
\hline $2^{\prime}$ & $3.93(\mathrm{dd}, 8.2,8.6)$ & 75.3 & $3.93(\mathrm{brt}, 8.5)$ & 75.3 & $3.92(\mathrm{dd}, 8.0,8.7)$ & 75.2 \\
\hline $3^{\prime}$ & $4.14(\mathrm{t}, 9.0)$ & 76.4 & $4.14(\mathrm{t}, 9.0)$ & 76.4 & $4.10(t, 9.0)$ & 76.4 \\
\hline $4^{\prime}$ & $4.38(t, 9.3)$ & 78.3 & $4.38(t, 9.3)$ & 78.3 & $4.38(\mathrm{t}, 9.1)$ & 78.2 \\
\hline $5^{\prime}$ & $3.63(\mathrm{~m})$ & 77.1 & $3.62(\mathrm{~m})$ & 77.1 & $3.60(\mathrm{~m})$ & 77.1 \\
\hline $6^{\prime}$ & $4.08(\mathrm{dd}, 2.6,11.4)$ & 61.3 & $4.08^{a)}$ & 61.3 & $4.05(\mathrm{dd}, 3.5,12.1)$ & 61.2 \\
\hline & $4.18^{a)}$ & & $4.19^{a)}$ & & $4.18(\mathrm{dd}, 1.7,12.5)$ & \\
\hline \multicolumn{7}{|c|}{ 等, } \\
\hline 1 & $5.82(\mathrm{brs})$ & 102.7 & $5.82(\mathrm{brs})$ & 102.7 & $5.81(\mathrm{brs})$ & 102.6 \\
\hline 2 & 4.68 (brs) & 72.5 & $4.67(\mathrm{dd}, 1.4,3.0)$ & 72.5 & $4.67(\mathrm{dd}, 1.5,3.2)$ & 72.5 \\
\hline 3 & $4.55(\mathrm{dd}, 3.3,9.2)$ & 72.7 & $4.53(\mathrm{dd}, 3.3,9.2)$ & 72.7 & $4.55(\mathrm{dd}, 3.3,9.3)$ & 72.6 \\
\hline 4 & $4.34(\mathrm{t}, 9.4)$ & 73.9 & $4.33(\mathrm{t}, 9.4)$ & 73.9 & $4.34(\mathrm{t}, 9.6)$ & 73.9 \\
\hline 5 & $4.95(\mathrm{dq}, 6.3,10.2)$ & 70.3 & $4.94(\mathrm{dq}, 6.2,9.5)$ & 70.3 & $4.93(\mathrm{~m})$ & 70.3 \\
\hline 6 & $1.69(\mathrm{~d}, 6.0)$ & 18.5 & $1.69(\mathrm{~d}, 6.2)$ & 18.5 & $1.69(\mathrm{~d}, 6.2)$ & 18.5 \\
\hline
\end{tabular}

a) Overlapping signals. 
In the NOESY spectrum, the presence of cross-peaks between $\mathrm{H}-24$ and $\mathrm{H}-25$ as well as $\mathrm{H}-3$ indicated that the methyl group (H-24) was axial, which in turn suggested that the carboxyl group at $\mathrm{C}-4$ was $\alpha$-positioned. In the HMBC spectrum, the carbonyl carbon signal at $\delta 175.1$ (C-28) showed a ${ }^{1} \mathrm{H}-{ }^{13} \mathrm{C}$ long range correlation with signals at $\delta$ $1.91(\mathrm{H}-18), \delta 1.58$, and $2.19(\mathrm{H}-22)$. The other carbonyl signal at $\delta 181.2(\mathrm{C}-23)$ was correlated with signals at $\delta 1.44$ (H-24) and 2.48 (H-5). These data indicate that the carbonyl groups of 1 are located at $\mathrm{C}-17$ and $\mathrm{C}-4$. In addition, HMBC correlations of 1 were observed between glc $\mathrm{H}-1^{\prime}\left(\begin{array}{ll}\delta & 6.30\end{array}\right)$ and the $\mathrm{C}-28$ of the triterpene moiety $(\delta 175.1)$, between glc $\mathrm{H}-1^{\prime \prime}(\delta 4.96)$ and glc C-6' $(\delta 69.3)$, and between rha H-1"' $(\delta$ $5.82)$ and glc $C-4^{\prime \prime}(\delta 78.3)$, which supported glycoside sequence. Two anomeric proton signals at $\delta 6.30(\mathrm{~d}, J=8.0 \mathrm{~Hz})$ and $4.96(\mathrm{~d}, J=7.9 \mathrm{~Hz})$ indicated a $\beta$-configuration based on coupling constants, and the $\alpha$-anomeric configuration of rhamnose was assigned based on the ${ }^{13} \mathrm{C}-\mathrm{NMR}$ chemical shift of rhamnosyl C-3 $(\delta 72.7)$ and C-5 $(\delta 70.3) .{ }^{17)}$ Acid hydrolysis of 1 provided the monosaccharide components of Lrhamnose and D-glucose (identified using authentic samples). Accordingly, the structure of 1 was elucidated to be $3 \alpha, 30$ dihydroxylup-20(29)-en-23,28-dioic acid 28- $O$-[ $\alpha$-L-rhamnopyranosyl-( $1 \rightarrow 4)$ - $\beta$-D-glucopyranosyl- $(1 \rightarrow 6)$ - $\beta$-D-glucopyranosyl] ester, which we named acankoreoside $\mathrm{F}$.

Compound 2 was obtained as a white amorphous powder of molecular formula $\mathrm{C}_{48} \mathrm{H}_{75} \mathrm{O}_{19}$, as determined by HR-FABMS (molecular ion $m / z 955.4899$ attributed to $[\mathrm{M}-\mathrm{H}]^{-}$). The ${ }^{1} \mathrm{H}$ - and ${ }^{13} \mathrm{C}-\mathrm{NMR}$ spectra of 2 indicated structural features similar to those of acankoreoside F (1) except for the presence of an aldehyde group at C-23. In the ${ }^{1} \mathrm{H}-\mathrm{NMR}$ spectrum of 2 , a singlet signal at $\delta 9.99$ corresponded to an aldehyde proton and signals at $\delta 4.42$ and 4.47 (each d, $J=15.3 \mathrm{~Hz}$ ) were assigned to hydroxylated methylene protons of $\mathrm{H}-30$. The ${ }^{13} \mathrm{C}$-NMR spectrum of $\mathbf{2}$ showed 48 signals including 18 sugar moiety signals, four tertiary methyl groups at $\delta 14.6$ (C-24), 16.4 (C-25), 16.5 (C-26) and 14.8 (C-27), olefinic carbons at $\delta 156.5$ (C-20) and 106.1 (C-29), and an aldehyde signal at $\delta 209.8$ (C-23). Two anomeric proton signals at $\delta$ $6.32(\mathrm{~d}, J=8.2 \mathrm{~Hz})$ and $4.95(\mathrm{~d}, J=7.6 \mathrm{~Hz})$ were characteristic of a $\beta$-configuration based on their coupling constants, and the $\alpha$-anomeric configuration of rhamnose was assigned based on the ${ }^{13} \mathrm{C}$-NMR chemical shift of rhamnosyl C-3 $(\delta$ $72.7)$ and $\mathrm{C}-5(\delta 70.3) .{ }^{17)}$ In the HMBC spectrum, the aldehyde signal at $\delta 209.8$ was correlated with the proton signal of a methyl group (H-24) at $\delta 1.09$. In addition, HMBC correlations of 2 were observed between glc H-1' $(\delta$ 6.32) and the $\mathrm{C}-28$ of the triterpene moiety $(\delta 175.0)$, between glc $\mathrm{H}-1^{\prime \prime}$ $(\delta$ 4.95) and glc C-6' $(\delta$ 69.3), and between rha H-1"' $(\delta$ $5.82)$ and glc $\mathrm{C}-4^{\prime \prime}(\delta 78.3)$, which the glycoside sequence. In the NOESY spectrum, the presence of cross-peaks between $\mathrm{H}-24$ and $\mathrm{H}-25$ as well as $\mathrm{H}-3$ indicated that the methyl group (H-24) was axially orientated, which in turn suggested that the carboxyl group at C-4 was $\alpha$-positioned. According to $2 \mathrm{D}$ NMR analysis, the structure of $\mathbf{2}$ was elucidated to be $3 \alpha, 30$-dihydroxylup-23-al-20(29)-en-28-oic acid 28- $O-\alpha$-Lrhamnopyranosyl- $(1 \rightarrow 4)-\beta$-D-glucopyranosyl- $(1 \rightarrow 6)-\beta$-Dglucopyranosyl ester, which was named acankoreoside $\mathrm{G}$.

Compound 3 was obtained as a white amorphous powder of molecular formula $\mathrm{C}_{48} \mathrm{H}_{75} \mathrm{O}_{20}$, as determined by HR-FABMS (molecular ion at $\mathrm{m} / \mathrm{z} 971.4863$ attributed to $[\mathrm{M}-\mathrm{H}]^{-}$).
The ${ }^{1} \mathrm{H}$ - and ${ }^{13} \mathrm{C}$-NMR spectra of $\mathbf{3}$ indicated a structure similar to that of acankoreoside E. ${ }^{14)}$ Its ${ }^{13} \mathrm{C}$-NMR spectrum exhibited five tertiary methyl groups at $\delta 14.6$ (C-24), $16.3(\mathrm{C}$ 25), 16.5 (C-26), 14.7 (C-27) and 10.0 (C-30). The C-23 signal ( $\delta$ 209.9) of 3 was significantly shifted by 5.3 ppm downfield as compared with that of acankoreoside $\mathrm{E}$ and the its carboxylic acid (C-29) at $\delta 180.0$ was shifted by $1.8 \mathrm{ppm}$ upfield, indicating the change in the functional groups at C-23 and C-29. Two anomeric proton signals at $\delta 6.33(\mathrm{~d}$, $J=8.0 \mathrm{~Hz})$ and $4.90(\mathrm{~d}, J=7.8 \mathrm{~Hz})$ were assigned to the $\beta$ configuration based on their coupling constants, and the $\alpha$ anomeric configuration of rhamnose was assigned based on the ${ }^{13} \mathrm{C}-\mathrm{NMR}$ chemical shifts of rhamnosyl C-3 $(\delta$ 72.6) and C-5 $(\delta 70.3) .{ }^{17)}$ In the NOESY spectrum, the presence of cross-peaks between $\mathrm{H}-24$ and $\mathrm{H}-25$ as well as $\mathrm{H}-3$ indicated that the methyl group (H-24) was axially orientated, which in turn suggested an $\alpha$-position for the carboxyl group at C-4. In the HMBC spectrum, the aldehydic carbonyl signal at $\delta$ 209.9 (C-23) was correlated with signals at $\delta 1.10$ (s, H-24) and 2.42 (brd, $J=13.3 \mathrm{~Hz}, \mathrm{H}-5$ ), and the carbonyl signal at $\delta$ 180.0 (C-29) with proton signals at $\delta 2.98$ (dq, $J=2.7$, $7.0 \mathrm{~Hz}, \mathrm{C}-20)$ and $1.28(\mathrm{~d}, J=6.9 \mathrm{~Hz}, \mathrm{H}-30)$, indicating that the aldehyde and carboxylic acid groups were present at $\mathrm{C}-4$ and $\mathrm{C}-20$ of the aglycone, respectively. In addition, HMBC correlations of 3 were observed between glc H-1' $(\delta 6.33)$ and the C-28 of the triterpene moiety ( $\delta$ 174.9), between glc $\mathrm{H}-1^{\prime \prime}(\delta 4.90)$ and glc C-6' $(\delta 69.3)$, and between rha H-1"' $(\delta$ $5.81)$ and glc $\mathrm{C}-4^{\prime \prime}(\delta 78.2)$, which supported the glycoside sequence. The downfield shift of the signal at $\delta 10.0$ (assigned to $\mathrm{C}$-30) in comparison with that of acankoreoside $\mathrm{E}$ $\left(\delta_{\mathrm{C}-30}: 7.0\right)$ also supported the above assignments. The absolute stereochemistry at C-20 was established using reported data for a similar compound. ${ }^{18,19)}$ The $S$ configuration at C-20 was established based on literature values for the chemical shifts of the carbonyl carbon at C-29 in $(20 S) 3 \beta$ acetoxylupan-29-oic acid $\left(\delta_{\mathrm{C}-30}: 9.6\right)$ and $(20 R) 3 \beta$-acetoxylupan-29-oic acid $\left(\delta_{\mathrm{C}-30}: 17.2\right)$. The carbon chemical shift difference between $\mathrm{C}-30$ of $(20 S)$ and $(20 R) 3 \beta$-acetoxylupan-29-oic acid was large enough to allow the differentiation. The chemical shift of C-30 $\left(\delta_{\mathrm{C}-30}: 10.0\right)$ in 3 was similar to that of $(20 S) 3 \beta$-acetoxylupan-29-oic acid. Thus, compound 3 was found to be (20S) $3 \alpha$-hydroxylup-23-al-28,29-dioic acid $28-O-\alpha$-L-rhamnopyranosyl- $(1 \rightarrow 4)$ - $\beta$-D-glucopyranosyl$(1 \rightarrow 6)$ - $\beta$-D-glucopyranosyl ester, which we named acankoreoside $\mathrm{H}$.

The three isolates $(\mathbf{1}-\mathbf{3})$ were assessed for anti-inflammatory activity by examining their effects on nitric oxide (NO) and prostaglandin $\mathrm{E}_{2}\left(\mathrm{PGE}_{2}\right)$ by lipopolysaccharide (LPS)-induced in RAW 264.7 cells. $^{20)} \mathrm{L}-N^{6}$-(1-iminoethyl) lysine (LNIL, $10 \mu \mathrm{M})$ and NS-398 were used as positive NO and PGE $_{2}$ production inhibitor controls, respectively. Acankoreoside $\mathrm{F}$ (1) at $200 \mu \mathrm{M}$ most potently inhibited $\mathrm{PGE}_{2}$ (59\%) and NO $(42 \%)$ production (data not shown).

\section{Experimental}

General Experimental Procedures Optical rotations were recorded on a JASCO D-1010 spectropolarimeter and an Autopol III Automatic polarimeter (Rudolph Research Flanders, NJ, U.S.A.). NMR spectra were measured in pyridine- $d_{5}$ on a Varian UI-500 spectrometer and chemical shifts are quoted relative to tetramethylsilane (TMS). HR-FAB-MS spectra were recorded on a JEOL JMS-700 instrument using glycerol as a matrix in negative ion mode. Diaion HP-20 (Mitsubishi Chem. Co.), Sephadex LH-20 (Pharmacia Biotech), silica gel 60 (0.04-0.063 mm, Merck) and LiChro- 
prep RP-18 (40-63 $\mu \mathrm{m}$, Merck) were used for open column chromatography. TLC was performed using silica gel $60 \mathrm{~F}_{254}$ plate (Merck).

Plant Material The leaves of $A$. koreanum NAKAI were collected from the Medical Plant Garden at Kyung Hee University during October 2003. Emeritus Professor Chang-Soo Yook (Department of Pharmacognosy at Kyung Hee University), one of the authors, identified the species. A voucher specimen (3-002-0067) was deposited at the Museum of Oriental Medicine in Kyung Hee University.

Extraction and Isolation Dried leaves $(1.0 \mathrm{~kg})$ were extracted twice with 1.51 of hot $\mathrm{MeOH}$ to provide $152.1 \mathrm{~g}$ of dried extract, which was chromatographed on a Diaion HP-20 column using $\mathrm{H}_{2} \mathrm{O} / 30 \%, 50 \%, 70 \%$, and $90 \% \mathrm{MeOH}$ mixes. The $70 \% \mathrm{MeOH}$ fraction was subsequently chromatographed on a silica gel column using $\mathrm{CHCl}_{3}-\mathrm{MeOH}-\mathrm{H}_{2} \mathrm{O}(8: 2: 0.2 \rightarrow$ $7: 3: 0.5)$ as eluent to give 8 fractions (Frs. $1-8)$. Fraction $4(6.46 \mathrm{~g})$ was then subjected to gel filtration chromatography on a Sephadex LH-20 column using $\mathrm{MeOH}$ as eluent. The saponin fraction $(5.95 \mathrm{~g})$ so obtained was chromatographed on a silica gel column using $\mathrm{CHCl}_{3}-\mathrm{MeOH}-\mathrm{H}_{2} \mathrm{O}$ $(7: 3: 0.2)$ as eluent and then by gradient chromatography on a LiChroprep RP-18 column using $\mathrm{H}_{2} \mathrm{O} / 50 \%$ to $90 \% \mathrm{MeOH}$ as eluent to yield compounds 2 (acankoreoside G, $63.8 \mathrm{mg}$, yield $0.006 \%$ ) and $\mathbf{3}$ (acankoreoside $\mathrm{H}, 44 \mathrm{mg}$, yield $0.004 \%)$. Fraction 7 (2.73 g) was subjected to Sephadex LH-20 column chromatography to give two fractions (Fr. 7-1 and Fr. 7-2). Fraction 7-2 $(1.08 \mathrm{~g})$ was purified by silica gel using $\mathrm{CHCl}_{3}-\mathrm{MeOH}-\mathrm{H}_{2} \mathrm{O}(8: 2: 0.2 \rightarrow$ $6: 4: 0.5)$ as an eluent and finally LiChroprep RP-18 column chromatographed using a gradient solvent system $(50 \rightarrow 90 \% \mathrm{MeOH})$ to yield compound 1 (acankoreoside F, $30 \mathrm{mg}$, yield $0.003 \%$ ).

Acankoreoside F (1): White powder; $[\alpha]_{\mathrm{D}}^{25}-43.0(c=0.50, \mathrm{MeOH}) ;{ }^{1} \mathrm{H}-$ and ${ }^{13} \mathrm{C}-\mathrm{NMR}$ data, see Tables 1 and 2; HR-FAB-MS $m / z[\mathrm{M}-\mathrm{H}]^{-} 971.4863$ (Calcd for $\mathrm{C}_{48} \mathrm{H}_{75} \mathrm{O}_{20}$ 971.4852).

Acankoreoside $\mathrm{G}(2)$ : White powder; $[\alpha]_{\mathrm{D}}^{25}-58.0(c=0.50, \mathrm{MeOH}) ;{ }^{1} \mathrm{H}-$ and ${ }^{13} \mathrm{C}-\mathrm{NMR}$ data, see Tables 1 and 2; HR-FAB-MS $m / z[\mathrm{M}-\mathrm{H}]^{-} 955.4899$ (Calcd for $\mathrm{C}_{48} \mathrm{H}_{75} \mathrm{O}_{19}$ 955.4903).

Acankoreoside H (3): White powder; $[\alpha]_{\mathrm{D}}^{25}-37.4(c=0.50, \mathrm{MeOH}) ;{ }^{1} \mathrm{H}-$ and ${ }^{13} \mathrm{C}-\mathrm{NMR}$ data, see Tables 1 and 2; HR-FAB-MS $m / z$ [M-H] ${ }^{-} 971.4863$ (Calcd for $\mathrm{C}_{48} \mathrm{H}_{75} \mathrm{O}_{20}$ 971.4852).

Acid Hydrolysis of 1 Compound 1 (25 mg) was hydrolyzed in 5\% $\mathrm{H}_{2} \mathrm{SO}_{4}$ under reflux for $3 \mathrm{~h}$. After neutralization with $\mathrm{NH}_{4} \mathrm{OH}$ followed by extraction with $\mathrm{CHCl}_{3}$, the aqueous layer was evaporated in vacuo to give a residue $(12 \mathrm{mg})$, which was subjected to silica gel column chromatography $\left(\mathrm{CHCl}_{3}-\mathrm{MeOH}-\mathrm{H}_{2} \mathrm{O}=6: 4: 1\right)$ to yield D-glucose and L-rhamnose. These sugars were compared with authentic samples on TLC and by measuring optical rotations $(+52.8,+12.5$, respectively).

Acknowledgements We thank the Korean Basic Science Institute at Korea University for providing NMR and HR-FAB-MS data. This research was supported by the Seoul Research and Business Development Program
(10524). In addition, we thank the Korean Ministry of Education \& Human Resources Development for support through the Post-BK21 program. We dedicate this work to the memory of Professor Sang-Yong Park our valued mentor and co-worker.

\section{References}

1) Kang J. S., Linh P. T., Cai X. F., Kim H. S., Lee J. J., Kim Y. H., Arch. Pharm. Res., 24, 407-411 (2001).

2) Park S. Y., Chang S. Y., Yook C. S., Nohara T., J. Nat. Prod., 63 , $1630-1633$ (2000).

3) Kang H. S., Kim Y. H., Lee C. S., Lee J. J., Choi I., Pyun K. H., Cell Immunol., 170, 212-221 (1996).

4) Hibasami H., Fujikawa T., Takeda H., Nishibe S., Satoh T., Fujisawa T., Nakashima K., Oncol. Rep., 7, 1213-1216 (2000).

5) Perry L. M., Metzger J., "Medicinal Plants of East and Southeast Asia," MIT Press, Cambridge, 1980, p. 41.

6) Bae K., "The Medicinal Plants of Korea," Kyo-Hak Publishing, Seoul, 2000, p. 361.

7) Cai X. F., Shen G., Dat N. T., Kang O. H., Kim J. A., Lee Y. M., Lee J. J., Kim Y. H., Chem. Pharm. Bull., 51, 605-607 (2003).

8) Cai X. F., Shen G., Dat N. T., Kang O. H., Lee Y. M., Lee J. J., Kim Y H., Arch. Pharm. Res., 26, 731-734 (2003).

9) Cai X. F., Lee I. S., Dat N. T., Shen G., Kang J. S., Kim D. H., Kim Y H., Arch. Pharm. Res., 27, 738-741 (2004).

10) Cai X. F., Lee I. S., Shen G., Dat N. T., Lee J. J., Kim Y. H., Arch Pharm. Res., 27, 825-828 (2004).

11) Cai X. F., Lee I. S., Dat N. T., Shen G., Kim Y. H., Phytother. Res., 18 $677-680$ (2004).

12) Chang S. Y., Yook C. S., Nohara T., Chem. Pharm. Bull., 46, 163165 (1998).

13) Chang S. Y., Yook C. S., Nohara T., Phytochemistry, 50, 1369-1374 (1999).

14) Park S. Y., Choi H. S., Yook C. S., Nohara T., Chem. Pharm. Bull., 53 97—99 (2005)

15) Sung T. V., Steglich W., Adam G., Phytochemistry, 30, 2349-2356 (1991).

16) Adam G., Lischewski M., Phiet H. V., Preiss A., Schmidt J., Sung T. V., Phytochemistry, 21, 1385-1387 (1982).

17) Kasai R., Okihara M., Asakawa J., Mizutani K., Tanaka O., Tetrahedron, 35, 1427-1432 (1979)

18) Corbett R. E., Cong A. N. T., J. Chem. Soc. Perkin Trans. 1, 1985, 2051-2056 (1985)

19) Corbett R. E., Cong A. N. T., Holland P. T., Wilkins A. L., Aust. J. Chem., 40, 461-468 (1987).

20) Hevel J. M., Marletta M. A., Methods Enzymol., 233, 250-258 (1994). 